Etikonomi

Volume 15 (1), April 2015

P-ISSN: 1412-8969; E-ISSN: 2461-0771

Page 63 - 74

\title{
THE IMPACT OF CORPORATE SOCIAL RESPONSIBILITY ON ACCRUAL EARNINGS MANAGEMENT AND REAL EARNING MANAGEMENT
}

\author{
Soliyah Wulandari \\ IAIN Sultan Maulana Hasanuddin Banten \\ soliyah.wulandari@gmail.com
}

\begin{abstract}
.
This study examines the influence of Corporate Social Responsibility on accrual earnings management and real earnings management. This study using control variables company size, KAP quality, and leverage. Sample of this study Obtained with purposive sampling for all non-financial company listed in the Indonesia Stock Exchange from 2001 to 2012. This study will use the data secondary, such as annual report. Data analysis will perform using multiple regressions. Result show that Corporate Social Responsibility is influence to accrual earnings management. Corporate Social Responsibility is a real influence to both abnormal earnings management of cash flow from operations and abnormal of production costs.
\end{abstract}

Keywords: corporate social responsibility; accrual earnings management; real earnings management

\begin{abstract}
Abstrak.
Penelitian ini menguji pengaruh Tanggung Jawab Sosial Perusahaan pada manajemen laba akrual dan manajemen laba riil. Penelitian ini menggunakan variabel kontrol ukuran perusahaan, kualitas KAP, dan leverage. Sampel penelitian ini diperoleh dengan purposive sampling untuk semua perusahaan non-keuangan yang terdaftar di Bursa Efek Indonesia dari tahun 2001 sampai 2012. Penelitian ini akan menggunakan data sekunder, yaitu laporan tahunan. Analisis data menggunakan regresi berganda. Hasil menunjukkan bahwa Tanggung Jawab Sosial Perusahaan berpengaruh terhadap manajemen laba akrual.

Kata Kunci: tanggung jawab sosial perusahaan; manajemen laba akrual; manajemen laba riil
\end{abstract}

Received: January 15, 2016; Revised: February 20, 2016; Approved: March 22, 2016 
The Impact of Corporate Social Responsibility on Accrual Earnings Management Soliyah Wulandari

\section{INTRODUCTION}

A form of accountability for management in running the company is financial statement. The financial statements provide an overview of the company's financial position, financial performance, and other information. The financial statements are an instrument for assessing management performance. Therefore, the management could have been an earning management to prepare financial statements reflecting management good performance. Healy (1985) proved that the managers do an earning management or use discretionary accruals to increase the compensation which they want to receive. The existence of earnings management that has been conducted by the management affected the financial statements which are prepared do not approach the reality of the economy.

Research on earnings management has a lot to do. Those studies focus on earnings management as a miss-statement (miss-presentation) or conceal the real economic performance. The two tools that are commonly used on earnings management are the accrual management and the real earnings management. In accrual management, the manager may borrow the profits from future periods through revenue acceleration or deceleration of expenses to increase current earnings. While the manipulation of real economic activity as a form of earnings management is done through the company operational activities manipulation.

Corporate Social Responsibility (CSR) is one of the elements which is expressed or presented at the company's annual report. Companies that provide a CSR information means inform financial statements users of that the company has a social awareness and environmental conservation. Reveal the activities related to social responsibility is common for analysts, investors and other stakeholders to demand greater transparency about all business aspects (Kim et al., 2012). The stakeholders have put a CSR as very important information. Grant Thornton (2008) stated that a CSR is no longer the domain of large companies whilst a must for all businesses. Proponent of CSR indicates that the company must be involved in the activities of social responsibility that provides benefits to many parties. 
The company's goal disclose the social responsibility activities as a form of corporate transparency to the financial statements users in line with the "transparent financial reporting hypothesis" or as a form of opportunistic companies to attract analysts, investors or other users, this is in line with the "opportunistic financial reporting hypothesis" (Kim et al., 2012). If the purpose of company is to express CSR in line with transparent financial reporting hypothesis, then the company would be likely to do little or no profit management. However, if the purpose of company is to express CSR in line with the financial reporting opportunistic hypothesis, then the company will tend to keep earning management.

Earnings management can be defined as "management intervention deliberately in the process of determination of the profits, usually to meet personal goals" (Schipper, 1989). This process often includes beautifying the financial statements, especially the numbers at the bottom i.e. profitability. Earnings management can be a "cosmetic", if the manager manipulates accruals that do not have cash flow consequences. Earnings management can also be "pure", if the manager chooses the action with consequent cash flows with the purpose of changing the profit (Subramanyam and Wild, 2009).

In accrual management, the manager may borrow the future period profits through revenue acceleration or deceleration of expenses to increase current earnings. Management profit earns future periods due to lower net income accelerated to current earnings (Healy, 1985; McNichols and Wilson 1988; Jones, 1991; Rangan 1998; Teoh et al., 1998; Phillips et al. 2003).

Manipulation of real economic activity as a form of profit management through manipulation of the company operational activities, such as providing discounted prices to increase sales and cut discretionary expenditures, such as research and development, to manage earnings (Baber et al., 1991; Dechow and Sloan, 1991; Bushee, 1998; Roychowdhury, 2006). Such actions can increase revenue or net income, but can also be harmful, for example, cutting research and development spending to manage earnings generate future earnings losses relating to previous research and development opportunities. 
The Impact of Corporate Social Responsibility on Accrual Earnings Management Soliyah Wulandari

Because of many criticisms to the conventional accounting that is deemed not accommodating the stakeholder interests, appearing new accounting concept i.e Corporate Social Responsibility (Aulia and Kartawijaya, 2011). The concept of CSR or triple bottom line is the concept of company's performance disclosure based not only on economic performance measures (such as acquisition of profit), but also the size of social awareness and environmental conservation. In addition to the pursuit of profit, the company must also play a role in preserving the planet and people social welfare. This concept is called 3BL (Triple Bottom Line) or 3P (Profit, People, Planet) (Santioso and Chandra, 2012). Hackston and Milne (1996) stated that the CSR is a process of communicating social and environmental impacts of organization economic activities to specific groups concerned and on society as a whole.

Trébucq and Russ (2005) in Kim et al. (2012) investigated the relationship between CSR and profit management. His research did not provide consistent results with earnings management relations CSR for the different dimensions of CSR. His research found that there was no relationship between CSR and earnings management when using net CSR score, but they found a negative relationship if using other specifications.

Chih et al. (2008) tested the CSR and profit management using multinational data. Research resulted that it does not show consistent results among earnings management proxy. CSR is more aggressively involved in the management of accrual earnings, but it is less involved in earnings smoothing and loss avoidance.

Kim, et al. (2012) examined the relationship between CSR and profit management. The samples are companies listed on the US capital markets. This study period is from 1991 to 2009. The results showed that there is a negative relationship between CSR with earnings management. These results indicate that the purpose of the company to express a CSR in line with transparent financial reporting hypothesis.

Because of analysts, investors and other users consider to CSR, why CSR is disclosing the information. CSR is done as a form of corporate transparency to the financial statement users in line with the "transparent financial reporting 
hypothesis" or as a form of opportunistic companies to attract analysts, investors or other users, this is in line with the "opportunistic financial reporting hypothesis" (Kim et al., 2012).

\section{METHOD}

The period of the sample in this study was between 2012 and 2013, but the financial statements and annual reports required in the study are from 2010 to 2013 , as this study requires a data $\mathrm{t}-1$ and $\mathrm{t}-2$. The sampling technique used in this research is purposive sampling which is a sampling technique with consider to some criterions. The sampling is based on the following considerations: (1) Nonfinancial companies that are consistently listed in the Indonesia Stock Exchange (BEI) from 2010 to 2013. (2) Non-financial companies that published financial statements in Indonesian Rupiah. (3) Non-financial companies that reported period as per 31 December each year. (4) Non-financial companies that have the required data in this study. Secondary data are used in this research such as nonfinancial corporation annual reports that listed on the Stock Exchange from 2010 to 2013 because in this study required a t-1 and t-2 data. Annual report obtained by downloading at www.idx.co.id.

The method that used in this paper was multiple linier regressions. This study uses three (3) control variables such as: firm size, leverage, and Quality of Public Accounting Firm (KAP). The reason of three control variables selection as in the previous study, the research conducted by these three variables proved effect on earnings management (Kim et al., 2012). The equations that used in this research are:

\section{Equation 1:}

ABS_DA $A_{t}=\alpha_{0}+\alpha_{1} C S R \_S C O R E+\alpha_{2} \operatorname{SIZE}_{t-1}+\alpha_{3} \mathrm{BIG}_{\mathrm{t}}+\alpha_{4} \mathrm{LEV}_{\mathrm{t}-1}+\varepsilon_{\mathrm{t}}$

Where:

$\begin{array}{ll}\text { ABS_DA } & \text { : absolute discretionary accruals } \\ \text { CSR_score } & : \text { score of CSR } \\ \text { SIZE } & : \text { firm size } \\ \text { BIG } & : \text { quality of public accountant } \\ \text { LEV } & : \text { leverage }\end{array}$


The Impact of Corporate Social Responsibility on Accrual Earnings Management

Soliyah Wulandari

\section{Equation 2:}

$\mathrm{AB} \_\mathrm{CFO}_{\mathrm{t}}=\alpha_{0}+\alpha_{1} \mathrm{CSR} \_\mathrm{SCORE}+\alpha_{2} \mathrm{SIZE}_{\mathrm{t}-1}+\alpha_{3} \mathrm{BIG}_{\mathrm{t}}+\alpha_{4} \mathrm{LEV}_{\mathrm{t}-1}+\varepsilon_{\mathrm{t}}$

Where:

AB_CFO : abnormal cash flow from operations

CSR_score : score of CSR

SIZE $\quad$ : firm size

BIG : quality of public accountant

LEV : leverage

\section{Equation 3:}

$\mathrm{AB} \_P R O D D_{\mathrm{t}}=\alpha_{0}+\alpha_{1} \mathrm{CSR} \_S C O R E+\alpha_{2} \mathrm{SIZE}_{\mathrm{t}-1}+\alpha_{3} \mathrm{BIG}_{\mathrm{t}}+\alpha_{4} \mathrm{LEV}_{\mathrm{t}-1}+\varepsilon_{\mathrm{t}}$

Where:

AB_PROD $\mathrm{t}$ : abnormal production

CSR_score : score of CSR

SIZE : firm size

BIG : quality of public accountant

LEV : leverage

\section{RESULT \& DISCUSSION}

This study used an observation period ( $\mathrm{t}$ ) and 2 (two) years sample period such as between 2012 and 2013. However, the researchers took company data from 2011 to 2013 for the measurement of the variables that needed financial statements for 2010 (t-2) i.e. real earnings management variable by proxy abnormal production (AB_PROD) and the financial statements of $2011(t-1)$ is the variable absolute discretionary accruals (ABS_DA), and abnormal cash flow from operations (AB_CFO).

Table 1 below gives an overview in detail the amount of the final sample used in this study. 
Table 1. Research Final Sample

\begin{tabular}{|c|c|c|c|}
\hline No. & Information & $\begin{array}{c}\text { Total } \\
\text { Company }\end{array}$ & $\begin{array}{c}\text { number of } \\
\text { observations }\end{array}$ \\
\hline 1 & $\begin{array}{l}\text { Consistent non-financial companies listed on } \\
\text { the Indonesia Stock Exchange in } 2010 \text { to } 2013\end{array}$ & 314 & 628 \\
\hline 2 & Companies that do not use Rupiah & $(57)$ & $(114)$ \\
\hline 3 & $\begin{array}{l}\text { Companies that period financial statements are } \\
\text { not per December } 31 \text { in the year } 2007 \text { to } 2011\end{array}$ & (1) & (2) \\
\hline \multirow[t]{4}{*}{4} & $\begin{array}{l}\text { Companies whose financial statements are not } \\
\text { complete }\end{array}$ & $(22)$ & $(44)$ \\
\hline & Samples before outlier test & 234 & 468 \\
\hline & number of outliers & & $(312)$ \\
\hline & Sample End & & 156 \\
\hline
\end{tabular}

Table 4.2 below presents the descriptive statistics main variables in a sample of non-financial companies listed on the Indonesian Stock Exchange (BEI).

Table 2. Descriptive Statistics

\begin{tabular}{lcrrrr}
\hline & $\boldsymbol{N}$ & Minimum & maximum & mean & Std. deviation \\
\hline CSR_SCORE & 156 & 0.00000 & 0.15190 & 0.05696 & 0.03759 \\
SIZE & 156 & 10.16590 & 19.32790 & 14.28196 & 1.90511 \\
BIG4 & 156 & 0 & 1 & 0.49000 & 0.50200 \\
LEV & 156 & 0.00010 & 4.70540 & 0.17386 & 0.39172 \\
ABS_DA & 156 & 0.00120 & 1.22060 & 0.12357 & 0.16012 \\
AB_CFO & 156 & -34.64350 & 3.81295 & -0.20444 & 2.84487 \\
AB_PROD & 156 & -3.03776 & 40.13744 & -0.39652 & 3.42607 \\
Valid N (listwise) & 156 & & & & \\
\hline
\end{tabular}

Hypothesis testing is done after the regression model free from classical assumptions symptoms. To answer whether this hypothesis is accepted or not, it is necessary to test the hypothesis. Here is an explanation of the results of the analysis and discussion.

\section{Testing Hypothesis 1}

Hypothesis 1 (equation 4) is intended to test whether Corporate Social Responsibility accrual effect on earnings management. The results of multiple regression testing are presented in Table 3 below: 
The Impact of Corporate Social Responsibility on Accrual Earnings Management Soliyah Wulandari

Table 3. Regression Results of Hypothesis 1

\begin{tabular}{lcccccc}
\hline \multicolumn{1}{c}{ Variable } & \multicolumn{2}{c}{ Coefficient Std. Error } & t-table & p.value & significance & Sign \\
\hline constants & 0.261 & 0.078 & 3.356 & 0.001 & & \\
CSR_SCORE & -2.355 & 0.333 & -7.079 & 0.000 & Significant & $(-)$ \\
SIZE & 0.005 & 0.005 & 0.963 & 0.337 & Not significant & \\
BIG4 & -0.208 & 0.026 & -8.148 & 0,000 & Significant & $(-)$ \\
LEV & 0.171 & 0.024 & 7.177 & 0.000 & Significant & $(+)$ \\
\hline
\end{tabular}

Dependent variable: ABS_DA

The results of the analysis that are presented in table 4.3 show that the disclosure of CSR affected on earnings management accrual by p-value of 0.000 . This means that the first hypothesis is supported that the existing empirical data consistent with disclosure of CSR predictions and affect the accrual earnings management. CSR coefficient shows a negative value that is equal to -2.355 . These results prove that the more of CSR disclosure made by companies, the smaller company that doing accrual earnings management. Control variables in this study are SIZE which does not affect to the accrual earnings management under a $p$-value of 0.337 . The quality audit (BIG4) affected on earnings management accrual with a $p$-value of 0.000 . Other control variables are leverage affected on earnings management accrual $p$-value of 0.000 .

\section{Testing Hypothesis 2}

Hypothesis 2 (equation 5) that uses proxy abnormal of cash from operations (AB_CFO) to measure the real earnings management intended to test whether the CSR accrual effect on earnings management. The results of multiple regression testing are presented in Table 4. 
Table 4. Regression Results of Hypothesis 2

\begin{tabular}{lrrrrrr}
\hline \multicolumn{1}{c}{ Variable } & Coefficient & Std. Error & t-table & p.value & significance & Sign \\
\hline constants & -0.278 & 0.107 & -2.611 & 0.010 & & \\
CSR_SCORE & 12.457 & 0.731 & 17.039 & 0.000 & Significant & $(+)$ \\
SIZE & -0.035 & 0.009 & -3.807 & 0.000 & Significant & $(-)$ \\
BIG4 & 0.364 & 0.034 & 10.574 & 0.000 & Significant & $(+)$ \\
LEV & 0.002 & 0.004 & 0.642 & 0.522 & Not significant & \\
\hline
\end{tabular}

Dependent variable: AB_CFO

The results of the analysis are presented in table 4.4 shows that CSR disclosures real effect on earnings management with $p$-value of 0.000 . This means that the first hypothesis is supported, which means that the existing empirical data in accordance with the predictions that CSR real effect on earnings management. CSR coefficient indicates a positive value that is equal to 12.457 . These results proved that the more of CSR disclosure made by companies made by companies, the more companies do accrual earnings management. Control variables in this study is SIZE that affect to real earnings management with a $p$-value of 0.000 . The quality audit (BIG4) affected on real earnings management with a p-value of 0.000 . Other control variables are leverage that did not affected to the accrual earnings management $p$-value of 0.522 .

\section{Testing Hypothesis 3}

Hypothesis 3 (equation 6) that uses proxy abnormal production costs (AB_PROD) to measure the real earnings management intended to test whether the Corporate Social Responsibility accrual effect on earnings management. The results of multiple regression testing are presented in Table 5. The results of the analysis, which are presented, show that CSR disclosures effect on real earnings management with p-value of 0.000 . This means that the first hypothesis is supported that the existing empirical data in accordance with the predictions that CSR effect on real earnings management. CSR coefficient shows a negative value that is equal -16.893 . These results prove that a growing number of CSR disclosure made by the company is getting a little company doing accrual earnings management. 
The Impact of Corporate Social Responsibility on Accrual Earnings Management Soliyah Wulandari

Table 5. Regression Results of Hypothesis 3

\begin{tabular}{lrrrrrr}
\hline \multicolumn{1}{c}{ Variable } & \multicolumn{2}{c}{ Coefficient Std. Error } & t-table & p.value & significance & Sign \\
\hline constants & -6.671 & 0,469 & -14.225 & 0,000 & & \\
CSR_SCORE & -16.893 & 1,316 & -12.841 & 0,000 & Significant & $(-)$ \\
SIZE & 0,573 & 0,040 & 14.225 & 0,000 & Significant & $(+)$ \\
BIG4 & -1.849 & 0,147 & -12.606 & 0,000 & Significant & $(-)$ \\
LEV & 0,151 & 0,144 & 1,050 & 0,296 & Not significant & \\
\hline
\end{tabular}

Dependent variable: AB_PROD

\section{CONCLUSION}

This study aims to demonstrate empirically the effect of disclosure of Corporate Social Responsibility (CSR) for the management of accrual earnings and real earnings management. Where accrual earnings management variables is approached by discretionary accruals, while real earnings management is proxy by abnormal of cash from operations and abnormal production costs. This study used a sample of non-financial companies listed on the Indonesia Stock Exchange. This research is the development of research Kim et al (2012) which has proved empirically the influence of Corporate Social Responsibility (CSR) on the quality of profit.

\section{REFERENCES}

Aulia, S. \& Kartawijaya. (2011). Analisis Penggunaan Triple Bottom Line dan Faktor Yang Mempengaruhi: Lintas Negara Indonesia dan Jepang (Analysis Triple Bottom Line Usage and Factors Affecting; Cross Country Indonesia and Japan). Presented at the National Symposium on Accounting XIV. Aceh.

Baber, W. et.al. (1991). The Effect of Concern about Reported Income on Discretionary Spending Decisions: The Case of Research and Development. The Accounting Review, Vol. 66, pp. 818-829.

Bushee, B. (1998). The Influence of Institutional Investors on Myopic R\&D Investment Behavior. The Accounting Review. Vol. 73, pp. 305-333. 
Chih, H. et.al. (2008). Corporate Social Responsibility, Investor Protection, and Earnings Management: Some International Evidence. Journal of Business Ethics, Vol. 79 (2), pp. 179-198.

Dechow, P. \& R. Sloan. (1991). Executive Incentives and the Horizon Problem: An Empirical Investigation. Journal of Accounting and Economics. Vol. 5, pp. 5189.

DeFond, M. \& K.R. Subramanyam. (1998). Auditor Changes and Discretionary Accruals. Journal of Accounting and Economics, Vol. 25 (1), pp. 35-67.

Ghozali, I. (2011). Aplikasi Analisis Multivariat dengan Program IBM SPSS 19 (Applications of Multivariate Analysis with IBM SPSS 19). Semarang: BP Universitas Diponegoro.

Healy, P. (1985). The Effect of Bonus Schemes on Accounting Decisions. Journal of Accounting and Economics, Vol. 7, pp. 201-210.

Jones, J. (1991). Earnings Management During Import Relief Investigations. Journal of Accounting Research. Vol. 29, pp.193-228.

Kim, Y. et.al. (2012). Is Earnings Quality Associated with Corporate Social Responsibility? The Accounting Review, Vol. 87, pp. 325-334.

Kothari, S. P. et.al. (2005). Performance Matched Discretionary Accrual Measures. Journal of Accounting and Economics, Vol. 39 (1), pp. 163-197.

McNichols, M. \& G. Wilson. (1988). Evidence of Earnings Management from the Provision for Bad Debts. Journal of Accounting Research. Vol. 26, pp. 1-31.

Phillips, J. et.al. (2003). Earnings Management: New Evidence Based on Deferred Tax Expense. The Accounting Review, Vol. 78, pp. 491-521.

Rangan, S. (1998). Earnings Management and the Performance of Seasoned Equity Offerings. Journal of Financial Economics, Vol. 102, pp. 101-122.

Roychowdhury, S. (2006). Earnings Management Through Real Activities Manipulation. Journal of Accounting and Economics, Vol. 42 (3), pp. 335-370. Santioso, Linda \& E. Chandra. (2012). Pengaruh Profitabilitas, Ukuran Perusahaan, Leverage, Umur Perusahaan, dan Dewan Komisaris Independen dalam Pengungkapan Corporate Social Responsibility (Effect of Profitability, Company Size, Leverage, Age Company, and the Board of Independent 
The Impact of Corporate Social Responsibility on Accrual Earnings Management

Soliyah Wulandari

Commissioners in the Disclosure of Corporate Social Responsibility). Journal of Business and Accounting, Vol. 14 (1), pp. 17-30.

Schipper, K. (1989). Commentary on Earnings Management. Accounting Horizons. pp. 91-102.

Subramanyam, K.R. et.al. (2009). Financial Statement Analysis Tenth Edition. New York: The McGraw-Hill Companies.

Teoh, S.H. et.al. (1998). Earnings Management and the Long-Run underperformance of Seasoned Equity Offerings. Journal of Financial Economics. Vol. 102, pp. 63-99. 